\title{
Morphology and ecology of a group of small, pelagic, tropical Tropocyclops (Crustacea, Copepoda, Cyclopoida), with the description of a new species from South China.
}

\author{
H.J. Dumont
}

Animal Ecology, Ghent University, Ledeganckstraat, 35, B-9000 Ghent, Belgium. E-mail : Henri.Dumont@ugent.be

Tropocyclops bopingi n.sp. is a $0.4 \mathrm{~mm}$ cyclopoid found in Liuxi He Reservoir, Guangdong, South China. It is probably widespread in South China, and appears in the Fauna Sinica under the name T. parvus. True T. parvus is a Central American species that is here redescribed from its type locality, Lake Petén Itzá in Guatemala. T. bopingi is related to T. tenellus from the limnetic zone of Lake Tanganyika and other lakes in Central Africa, and all of them live under climatic conditions that are transitory between subtropical and tropical. T. tenellus is even smaller and more buoyant than T. bopingi and, at least in Lake Tanganyika, it tends to occur closer to the water surface than other zooplankton during the daytime. It does not carry egg balls, but extrudes eggs one at a time. T. tenellus and T. bopingi appear morphologically closer to each other than to T. parvus, but all three are ecologically similar: extremely small, pelagic species that presumably feed on small particles in the water. I hypothesize that environmental conditions in subtropical-tropical transition zones combine with predation and competitive pressure to offer a selective advantage to such omnivorous species in the open water of large lakes or reservoirs.

Keywords: zooplankton, taxonomy, ecology, Tropocylops, tropical lakes

\section{Introduction}

The eucyclopine genus Tropocyclops, with a predominantly tropical-subtropical range (for a catalogue of named species and subspecies, see Dussart \& Defaye 1985 ) is composed of small to very small species that predominantly occupy the weedy littoral of lakes and ponds. A few species occur in the limnetic zone of large lakes, however. They are characterized by their small size (under $0.5 \mathrm{~mm}$ total length). The first of these, Tropocyclops tenellus (Sars, 1909) was described from the pelagic of Lake Tanganyika. Sars' description of the female was rather complete (yet including the wrong P5), but the male was ignored. This species and its close relatives were initially believed to share with $T$. confinis a characteristic spine number $(3: 4: 3: 3)$, on the outside of the apical segments of exopodites of P1-P4 (=exP1-4). These relatives include T. parvus Kiefer 1931, from Lake Petén Itzá, Guatemala, Central America, prematurely synonymized by Dussart \& Defaye (1985) with T. tenellus. Other records of T. tenellus or tenellus-like animals are from Madagascar (Dussart 1982), Lake Mweru (Moero) on the border between Congo and Zambia, and its environs (Harding 1942, Einsle 1971), and Southern China (Shen et al. 1979, sub T. parvus). There is considerable uncertainly whether all these records truly represent the same species. Tropocyclops is currently one of the most intractable genera of the cyclopoids, and needs revision. The Tropocyclops tenellus group, although apparently defined by its thoracopodal spine formula and other characters that will be discussed further on, is certainly no exception. The discovery and description of a new species in this group from Liuxi He Reservoir in Guangdong Province, South China, prompted the present redescription of T. tenellus and T. parvus, and a discussion of their ecology.

\section{Material and methods}

I used formalin or ethanol-preserved collections of zooplankton from which specimens were pipetted under a binocular microscope, transferred to a drop of glycerol on a glass slide, dissected using tungsten needles, covered by a cover slip, and permanently mounted using an insulating varnish. All drawings were made under an 
Olympus BX40 microscope equipped with a drawing tube, under oil immersion and phase contrast. Plankton collections were freshly made from the type locality in the case of Tropocyclops bopingi (in May 2005 and 2006) and T. parvus (in March 2006), using $50 \mu$ m dip nets. Collections from Lake Tanganyika (T. tenellus) were obtained from Prof. J-P. Descy (Namur, Belgium), and extend from 2003 to 2005, mainly at Kigoma and Mpulungu (Congo). They include two series of differential vertical plankton-net hauls, on 17. 08. 2004 and 3. 8. 2005 (0-20 m, 20-40 m, 40-60 m, 60-80 m, 80-100 m) that allowed me to establish the vertical distribution of Tropocyclops tenellus in relation to that of the other crustaceans of the plankton. Microphotographs were made using an Olympus 5.1 megapixel camera fitted to the BX40 microscope. Stacks of pictures were treated with Heliconfocus software to obtain an improved focus. Pencil drawings were mounted, scanned into a computer, and finished using the Photoshop program (version 8.0).

\section{Abbreviations}

The nomenclature of copepod body parts, and their abbreviations follow Huys \& Boxshall (1991). A1, antennule; A2, antenna, P1-P4, swimming legs; P5-P6, rudimentary legs; Enp, endopodite; Exp, exopodite. Thus, for example, the third segment of the exopodite of swimming leg 4 is abbreviated as Exp3P4.

\section{Species descriptions}

\section{Tropocyclops tenellus Sars, 1909.}

Figs 1-6.

Type locality: Lake Tanganyika, Central Africa.

Material examined: Several thousands of females and males from Bujumbura Bay (Burundi), May 1983, and from Mpulungu (Zambia) and Kigoma (Tanzania), spanning the north to the south of the lake, June 2003 - August 2005.

Diagnosis - One of the smallest Tropocyclops known (female total length under $0.4 \mathrm{~mm}$, Figure 1A), of the $3: 4: 3: 3$ group, without seta at the inner apical angle of segment 1 of the exopodites of $\mathrm{P} 3$ and $\mathrm{P} 4$ and on the basipodite of $\mathrm{P} 1$. The spine on exp1P3 somewhat sinuous, but running parallel with the spine on segment 2 . Of the five spines on expP4, spines 1 (on basal segment) to 3 (basalmost spine of third segment) distinctly shorter than spine 4 (middle spine of ex3P4). Intercoxal sclerite of P4 slightly widened apically, its free border somewhat convex and lined with minute, subapically implanted spines.

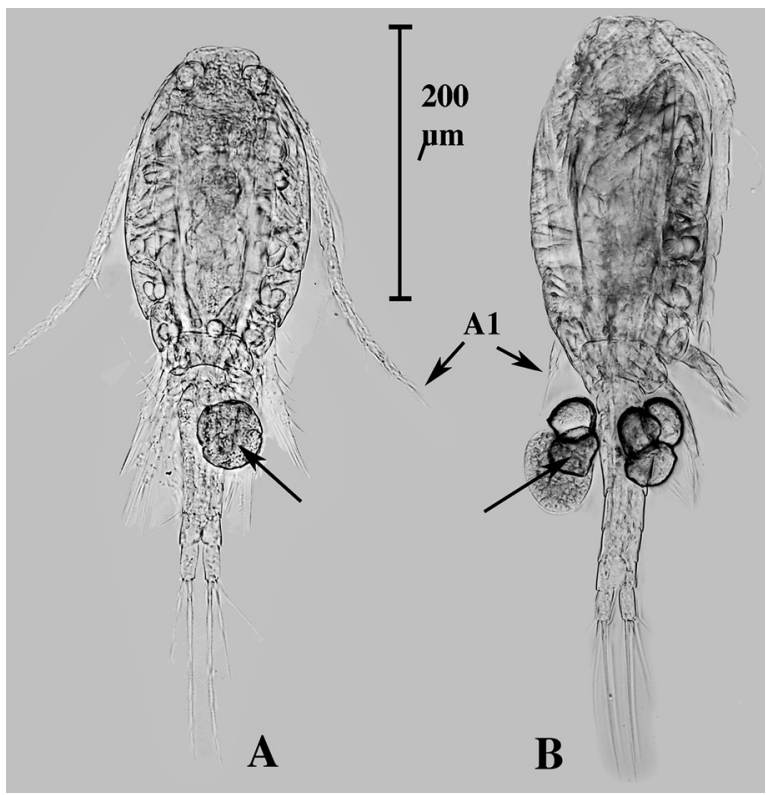

Fig. 1. Photograph of ovigerous females of A. Tropocylops tenellus, B. T. bopingi n. sp. Length of the antennule (A1) and eggs arrowed. Note the difference in size between the two taxa.

A1 with long setae on segments 1, 4, 8 and 9. A2 without spinules on basipodite. Furca with dorsal seta about $75 \%$ the length of outer medial seta. Inner medial seta almost twice as long as outer medial seta. Inner and outer terminal setae of same length. None of the appendages of the maxilla claw-like.

Male. A1 with segment 11 widened and with oblique furrow but without movable hook. P6 with three appendages.

Description of the female - Colour grey, shape rather robust (Fig. 1A). Body length (from tip of furcal rami to tip of rostrum) $0.320-0.360 \mathrm{~mm}(\mathrm{n}=20)$. Lake Tanganyika females do not carry egg-sacs (see further). A1 of 12 segments, stretching to beyond the posterior border of the cephalosome (Fig. 1A, arrowed). Segments 1 and 712 elongated, segments 2-6 shortened (Fig. 2). Long plumose setae on segments 1, 4, 8 and 9. The seta on segment 9 reaches far beyond the tip of the antennule, that on segment 4 reaches to the base of segment 11 , and that on segment 10 reaches the tip of the antennule. No esthetascs seen. Basipodite of A2 (Fig. 3A) without spine patterns, its exopodites 2 and 3 with a short row of inner apical setules. Mandibles and maxillulae much as in T.jamaicensis Reid \& Janetzky. Maxilla without claws: all setae more or less equally strongly built and the two setae on segment 4 subequal in length (Fig. 4B). Maxilliped slenderly built, with only two setae on the apical segment (Fig. 4A) 


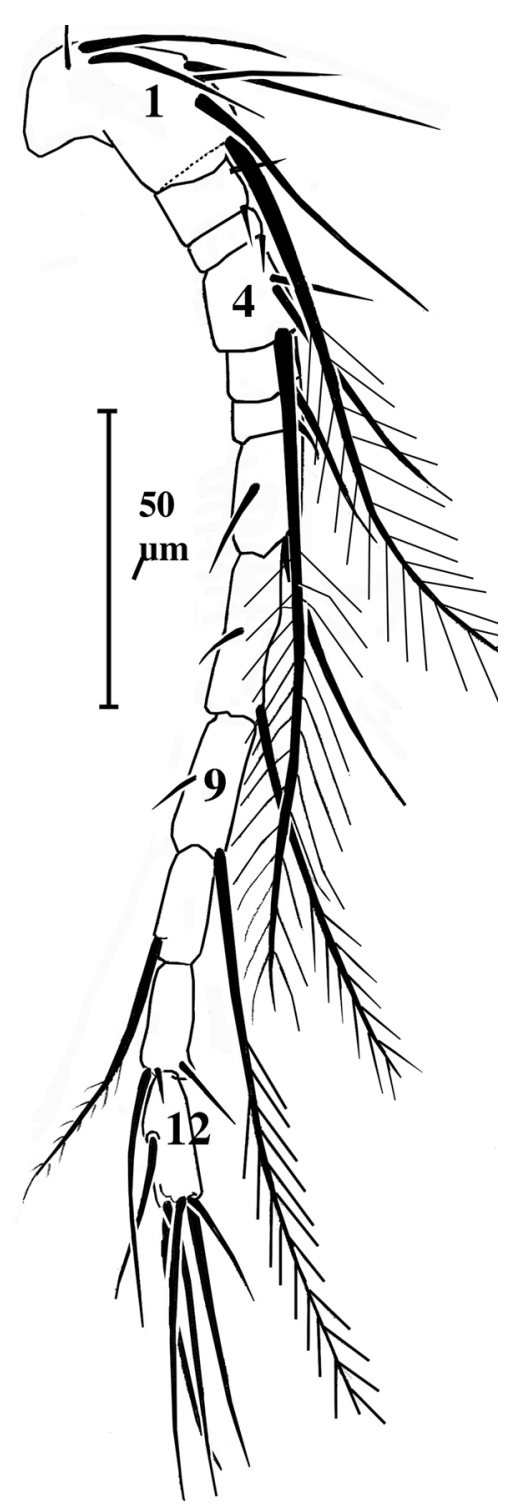

Fig. 2. T. tenellus Sars, female. A1.

P1-P4 with triarticulate rami (Fig. 5). Spine and seta formula as in Table 1. No spine rows seen on basi- and coxopodites. Number of spines on exp3 P1-P4 3:4:3:3. Basis of P1 devoid of medio-internal seta. Intercoxal sclerite with a couple of bulges, but without spines or hairs. External spines on exp1P3 and exp2P3 somewhat curved, but spine on segment 1 parallel with spine on segment 2. No seta on inner distal angle of exp1P3 and exp1P4. Of the 4 external spines of expP4, the basalmost 3 are short and of the same length, while the distalmost one is about twice their length. Intercoxal sclerite of P4

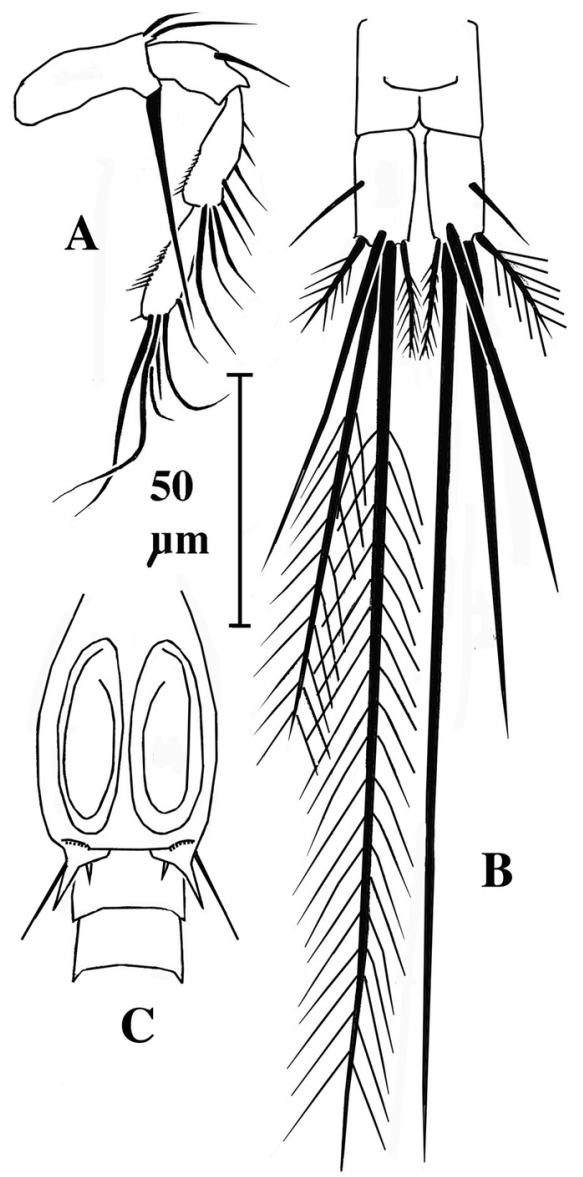

Fig. 3. T. tenellus Sars. A. Female A2, B. Female Furca, C. Male P6.

distally somewhat widened, its free margin convex and with a row of minute (sub)apical spinules. P5 of one segment, with three appendages. Internal spine relatively short, external setae long and slender. Receptaculum seminis complex, much like in T. bopingi (see further). In spite of the large number of specimens checked, no females with egg sacs were found, but two females carried a single egg (Fig. 1A).

Furcal rami (Fig. 3B) about twice as long as wide. Lateral seta inserted at about mid-length. Internal and external terminal setae plumose, of the same length or the internal one slightly longer. External median seta slightly over half as long as internal median seta; the latter about 8 times as long as the furcal rami. Dorsal seta long, three times as long as furcal rami, reaching up to $75 \%$ of the length of the external median seta. 


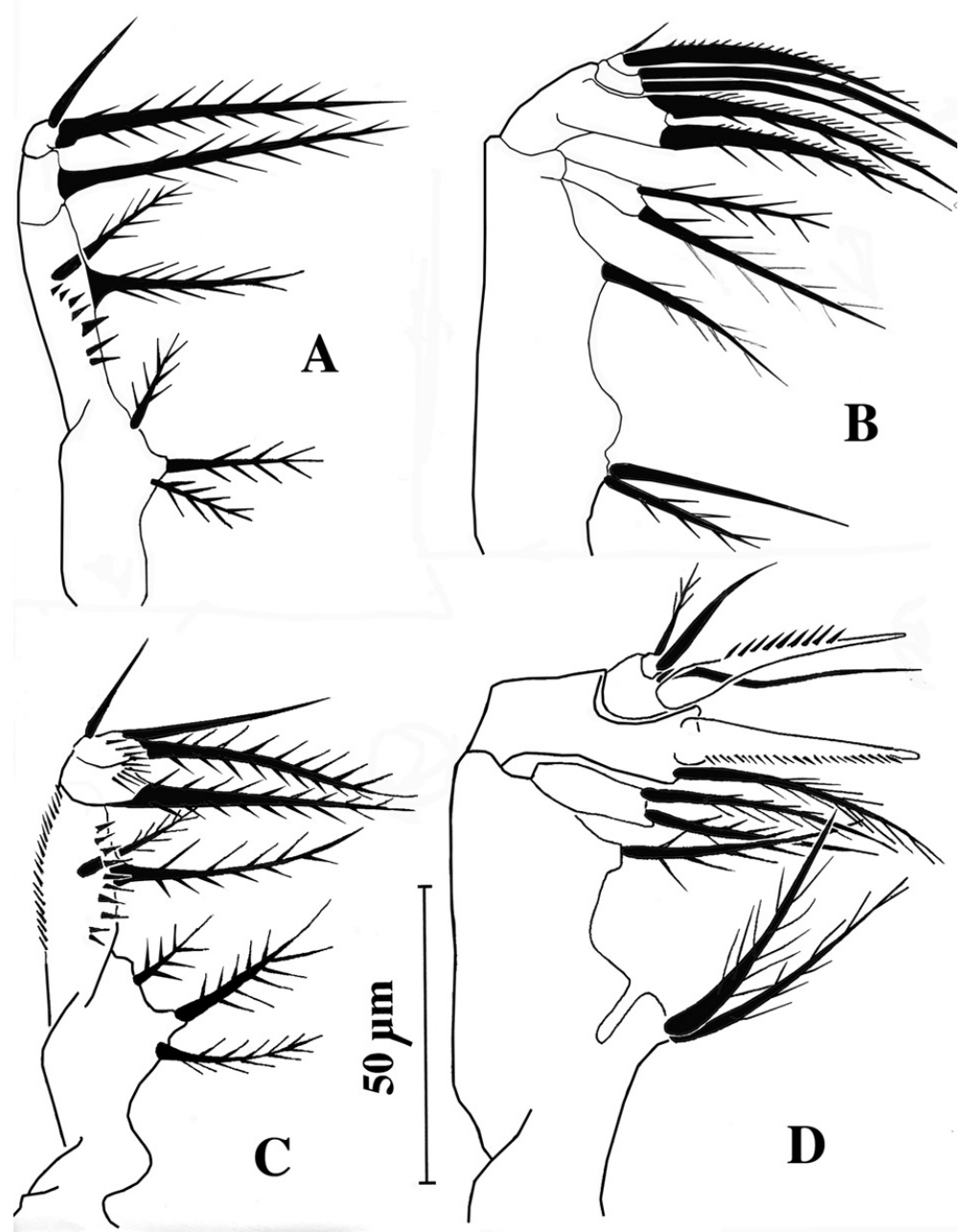

Fig. 4. A, B: T. tenellus Sars, female, maxilliped and maxillula; C, D: T. parvus Kiefer, female maxilliped and maxillula.

Males - Smaller than females (total length 0.30 - 0.33 $\mathrm{mm})$. A1 of 16 segments, with a major articulation between segments 14 and 15 (Fig. 6), and with strong plumose setae on segments 1,3 , and 4 , extending to level of geniculation or beyond. Long seta at base of segment 16, and longest setae in the tuft at the tip of segment 16 distinctly longer than the segment itself. Segments 4-9 strongly telescoped into each other and difficult to discern individually. Segment 11 large and widened, with a furrow running obliquely around it, but without a movable hook, and with only a short spine in its apical third. Segments 12 and 13 with a spinulated thorn. All other appendages like in female, except P6, which consists of a small, more or less triangular plate on each side of the genital segment, bearing 3 appendages (Fig. 3C).
Vertical distribution of the Lake Tanganyika population - The samples examined, collected at biweekly intervals during May 1983 and from May till September 2003 and 2004, showed no significant trend in overall abundance, except for clear evidence of patchiness (some species abundant in one samples, but rare in a parallel sample). Interestingly, the differential daytime vertical plankton hauls of 17 August 2003 and 3 August 2005 at Mpulungu showed abundant Tropocyclops tenellus populations between the lake surface and $40 \mathrm{~m}$. depth, but not a single specimen between 50 and $70 \mathrm{~m}$ and deeper (few specimens were seen in another sample, hauled between 40 and $60 \mathrm{~m}$ ). The suggestion here is that an abrupt decrease in Tropocyclops occurs below $40 \mathrm{~m}$, where Mesocyclops, Tropodiaptomus, the Tanganyika shrimp Limnocaridina spp. and the Tanganyika medusa 
Table 1. Spine-and-setae formule of $\mathrm{P}_{1}-\mathrm{P}_{4}$. Roman symbols = spines; Arabic symbols = setae. Discriminating characters are in bold.

\begin{tabular}{|c|c|c|c|c|c|c|c|c|}
\hline \multicolumn{9}{|c|}{ T. tenellus } \\
\hline & & & \multicolumn{3}{|c|}{ Exopodite } & \multicolumn{3}{|c|}{ Endopodite } \\
\hline & Coxa & Basis & 1 & 2 & 3 & 1 & 2 & 3 \\
\hline $\operatorname{leg} 1$ & $0-1$ & $1-0$ & I-1 & I-1 & III,I+1,3 & $0-1$ & $0-2$ & $1, \mathrm{I}+1,3$ \\
\hline $\operatorname{leg} 2$ & $0-1$ & $1-0$ & $\mathrm{I}-1$ & $\mathrm{I}-1$ & III, I+1,4 & $0-1$ & $0-2$ & $1, \mathrm{I}+1,3$ \\
\hline $\operatorname{leg} 3$ & $0-1$ & $1-0$ & I-0 & I-1 & II, I+1,4 & $0-1$ & $0-2$ & $1, \mathrm{I}+1,3$ \\
\hline leg 4 & $0-1$ & $1-0$ & I-0 & I-1 & II, I+1,4 & $0-1$ & $0-2$ & $1, \mathrm{II}, 2$ \\
\hline \multicolumn{9}{|c|}{ T. bopingi } \\
\hline $\operatorname{leg} 1$ & $0-1$ & $1-1$ & I-1 & $\mathrm{I}-1$ & III, I+1,3 & $0-1$ & $0-2$ & $1, \mathrm{I}+1,3$ \\
\hline $\operatorname{leg} 2$ & $0-1$ & $1-0$ & I-1 & I-1 & III, I+1,4 & $0-1$ & $0-2$ & $1, \mathrm{I}+1,3$ \\
\hline $\operatorname{leg} 3$ & $0-1$ & $1-0$ & I-1 & I-1 & II, I+1,4 & $0-1$ & $0-2$ & $1, \mathrm{I}+1,3$ \\
\hline $\operatorname{leg} 4$ & $0-1$ & $1-0$ & I-1 & $\mathrm{I}-1$ & II, I+1,4 & $0-1$ & $0-2$ & 1, II, 2 \\
\hline \multicolumn{9}{|c|}{ T. parvus } \\
\hline $\operatorname{leg} 1$ & $0-1$ & $1-1$ & I-1 & I-1 & III, I+1,3 & $1-1$ & $1-2$ & $1, \mathrm{I}+1,3$ \\
\hline $\operatorname{leg} 2$ & $0-1$ & $1-0$ & I-1 & I-1 & III, I,4 & $0-1$ & $0-2$ & $1, \mathrm{I}+1,3$ \\
\hline $\operatorname{leg} 3$ & $0-1$ & $1-0$ & I-1 & I-1 & II(III), I+1,4 & $0-1$ & $0-2$ & $1, \mathrm{I}+1,3$ \\
\hline leg 4 & $0-1$ & $1-0$ & I-1 & I-1 & II, I+1,4 & $0-1$ & $0-2$ & 1,II, 2 \\
\hline
\end{tabular}

Limnocnida tanganyicae were much more common than in the layers above.

\section{Tropocyclops parvus Kiefer, 1931.}

Figs 7-9.

Type locality: Lake Petén Itzá, Guatemala.

Material examined: a series of males and females from Lake Petén Itzá, collected by hauling a 100 micrometer plankton net vertically and horizontally through the open water of the lake, March 2006.

Diagnosis-A small (female body size about $0.45 \mathrm{~mm}$ ) Tropocyclops with spine formula 3:4:3:3 or 3:4:4:3, with both formulae sometimes present on the left and right side of a single specimen. A seta present on the basipodite of P1 and on the inner margin of expP1-P4. Distal angle of enp1P3 and enp2P3 spinous, and with small chitinous $\mathrm{knob}$ at the foot of each spine. En3P4 with long apical spine. Plumose seta on segment 1 of A1 reaching to segment 8 ; that on segment 4 reaching to segment 8 and that on segment 9 reaching to the base of segment 12 . Setules along external margin of exopodite 2 of A2 all about the same length. Furca with slightly divergent rami; dorsal furcal seta less than half as long as external median seta. Maxilla with two claw-like setae.
Male-A1 with a robust movable hook on segment 11, extending apicad beyond segment 12; P6 with two spines.

Description of the female - A rather stoutly built, greyish Tropocyclops, with body size 0.44-0.46 millimeters. Egg sacs small, held above the body. A1 of 12 segments, stretching over most of the cephalosome but not reaching its posterior end. Segments 1, 4, 7-12 elongated, the others rather short (Fig. 7B). Long plumose setae on segments 1,4 , and 9 . The seta on segment 1 stretching as far as halfway segment 8 ; that on segment 4 stretching to top of segment 9 , and that on 9 reaching the basis of segment 12. No esthetascs seen. A2 (Fig. 7C) with the series of setae on the outside of exopodite 2 all of about the same length. A row of spinules, increasing in length distally, on its inner side. A short row of spinules also on the inner margin of exopodite 3.

Mandibles and maxillula as in preceding species. Maxilla with subapical segment provided with a seta and a strong spine (Fig. 4A), and segment 3 adorned with a seta and a claw. The two setae on segment 4 of the same length. Maxilliped with four setae on apical segment (Fig. 4C).

Swimming legs with spine formula $3: 4: 3: 3$, but frequently also $3: 4: 4: 3$, and sometimes the left branch of P3 

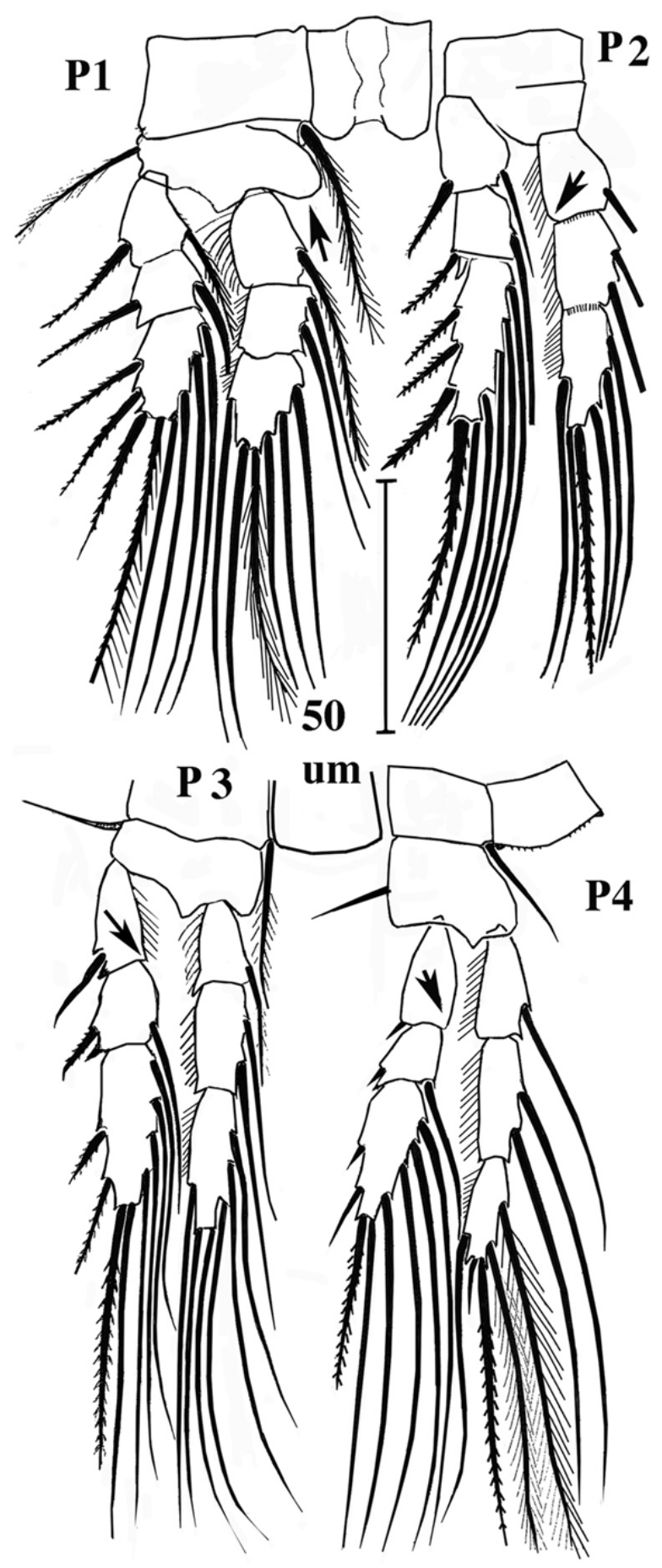

Fig. 5. P1-P4 of Tropocyclops tenellus Sars, female.

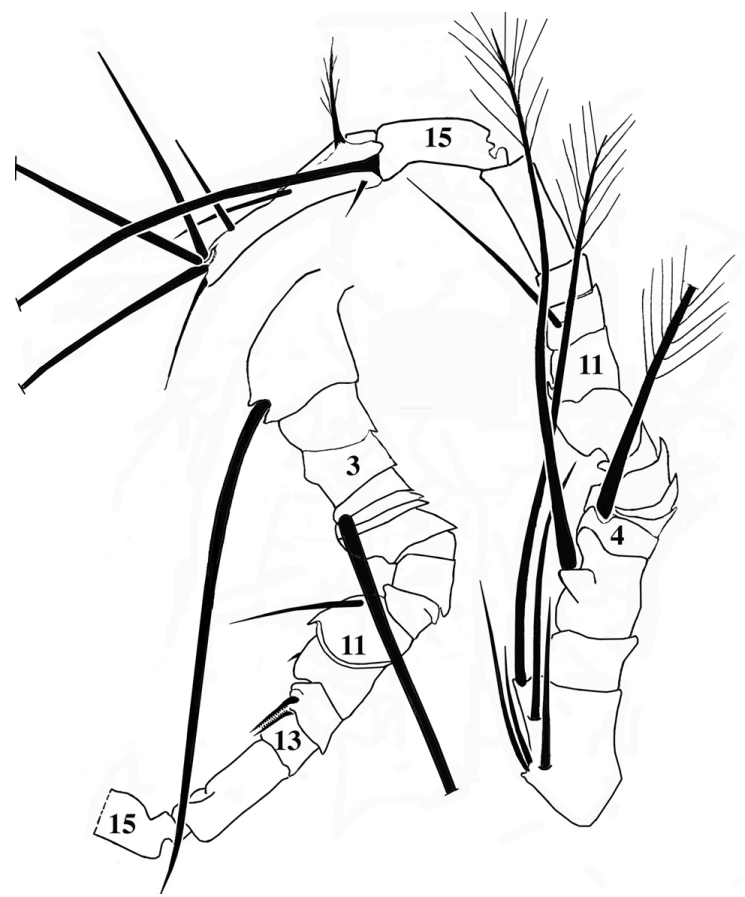

Fig. 6. Tropocyclops tenellus Sars, male A1.

in a single individual may have 3 spines, the right branch 4 (Fig. 8). In some cases, the extra spine is rudimentary (Fig. 8, Ex3P4). No spines on basi- and coxopodites, except for two small rows on frontal side of P2. Basipodite of $\mathrm{P} 1$ with a long seta and a seta at the inner margin of exp1P1-P4. Intercoxal sclerite of P3 with few long and fine setules, that of P4 with only few rows of finest spinules. Outer margin of segments 1 and 2 of the exopodites and endopodites of $\mathrm{P} 3$ produced in a short apical spine, bearing a small chitinous knob on its inside. Enp3P4 with long apical spine, just over two times as long as its segment. Short apical spine about four times shorter than long apical spine. P5 of one segment, bearing a rather long internal spine and two long plumose seta. Furcal rami slightly divergent, about twice as long as wide, with lateral setae implanted slightly beyond halfway (Fig. 7A). Internal apical seta somewhat longer than external apical seta. Median setae plumose, the internal one about 1.6 times as long as the external one. Dorsal seta longer than internal apical seta, yet distinctly less than half as long as external median seta.

Description of the male - Somewhat smaller than female (total length about $0.4 \mathrm{~mm}$ ). A1 of 16 segments, geniculated between segment 14 and 15. Segments 11 and 12 swollen and expanded. Segment 11 with a large movable hook, extending apicad to about halfway segment 13 (Fig. 9A). None of the "long" setae on segments 


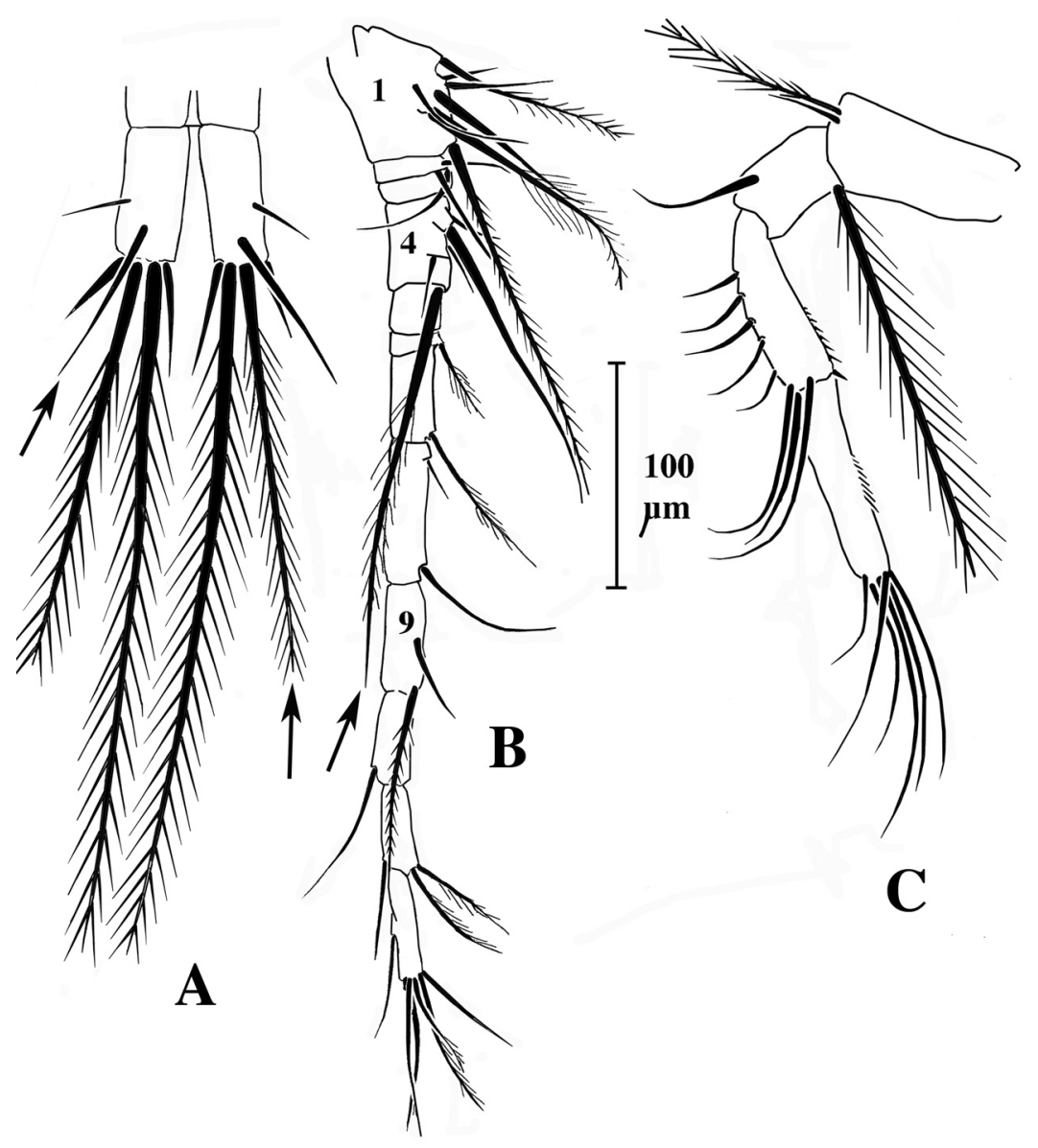

Fig. 7. Tropocyclops parvus Kiefer, female. A. Furcal rami, B. A1, C. A2.

1-6 reaching level of geniculation. Seta at base and in apical tuft on segment 16 shorter than that segment. All other appendages as in female, except P5, which has an even longer spine (Fig. 9B), and P6, which bears 2 appendages.

\section{Tropocyclops bopingi n.sp.}

syn. Tropocylops parvus Shen et al., 1979.

Figs 10-15.

Type locality: The reservoir on the Liuxi He River known as Liuxi He Reservoir, Guangdong Province, South China, close to the city of Guangzhou (Canton), 13.06.2005. Collected again in May 2006. For details about the locality, see Lin et al. (2003). Type material collected by vertical hauling of a 50 micrometer plankton net in the open water of the lake, about $500 \mathrm{~m}$ from the dam. Examination of other samples in the collection of the Hydrobiological Research Institute of Jinan University revealed that the species is almost perennial in the pelagic space of the reservoir and that it also occurs in other reservoirs in Guangdong Province (e.g. Dajingshan Reservoir, Zhuhai).

Material: Numerous egg-bearing females; a series of males. The holotype, an undissected female, is mounted in glycerol on a glass slide and deposited at the "Center of Animal Evolution and Systematics", Institute of Zoology, Chinese Academy of Sciences, Beijing, accession number $\mathrm{CO}$ 000001, together with three slides (CO 000002-4), containing about 10 female paratypes, partly dissected. A further slide with five females, partially dissected, is deposited at the Institute of Natural Sciences, Brussels. A tube with an alcohol-glycerin mixture, containing about 10 adult females and 10 males, all with 


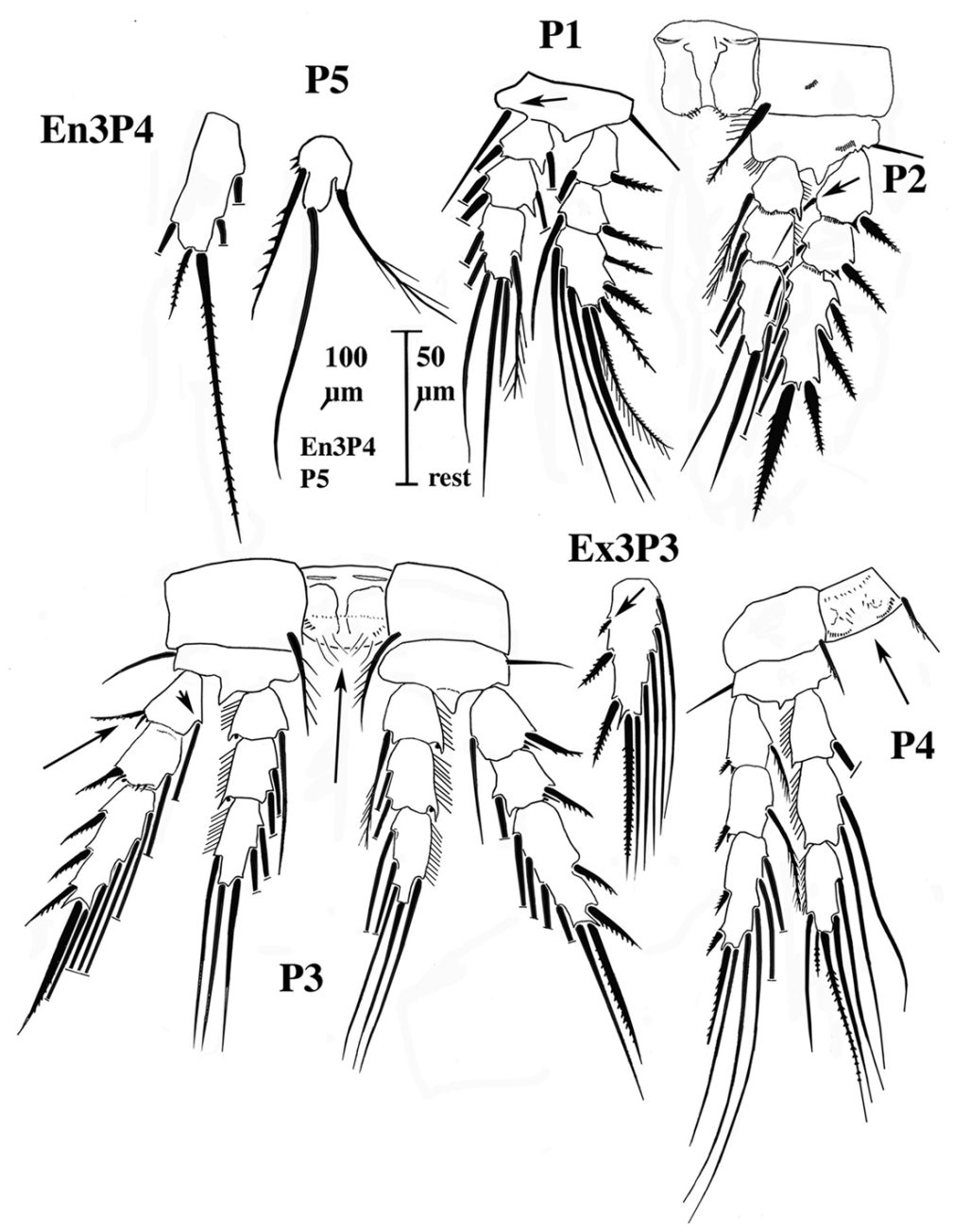

Fig. 8. Tropocyclops parvus Kiefer, female. P1-P4.

paratype status, is also deposited at the same institution under accession number IG 30644 (copepod collection numbers COP 4747 and 4748).

Origin of the name - I name this species in honour of Dr. Boping Han of the Jinan University, Guangzhou, who took me to the lake and provided friendship and assistance during my consecutive stays in Guangzhou.

Diagnosis - A small (total length around $0.4 \mathrm{~mm}$ ) Tropocyclops of the 3:4:3:3 group, with setae on the inner apical angle of segment 1 of all exopodites, a seta on the basipodite of $\mathrm{P} 1$, the spine on exp1P3 sinuous and at a sharper angle with its segment as the spines on segments 2 and 3; the spine on exp1P4 shorter than those on segments 2 and 3, the intercoxal sclerite of P4 not widened apically and with a convex free border, lined with a row of spinules on either side. A 1 with long setae at the tip of seg- ments 1, 4 and 9; the seta on segment 4 particularly long and plumose. No esthetascs seen. A2 without spinule patterns on basipodite; segments 2 and 3 of exopodite with few spinules apically on inner side. Maxilla with one claw-like seta. Furca with divergent rami; dorsal apical seta only little longer than half the outer medial seta; inner medial seta only about one fourth longer than outer median seta; inner apical seta distinctly longer than outer.

Description of mature female - Colour greyish-green; shape compact, fusiform; body length $0.38-0.42 \mathrm{~mm}$ $(n=10)$ (Figs 1B, 10). Egg-sacs small, of 1-5 eggs, held almost above the body. A1 of 12 segments, stretching to the end of the cephalosome, about $230 \mu \mathrm{m}$ long. Segments 1 and 7-12 elongated, segments 2-6 squarish or rectangular. Long and plumose setae on segments 1, 4, 9, 10. The long seta on segment 4 reaches as far as segment 


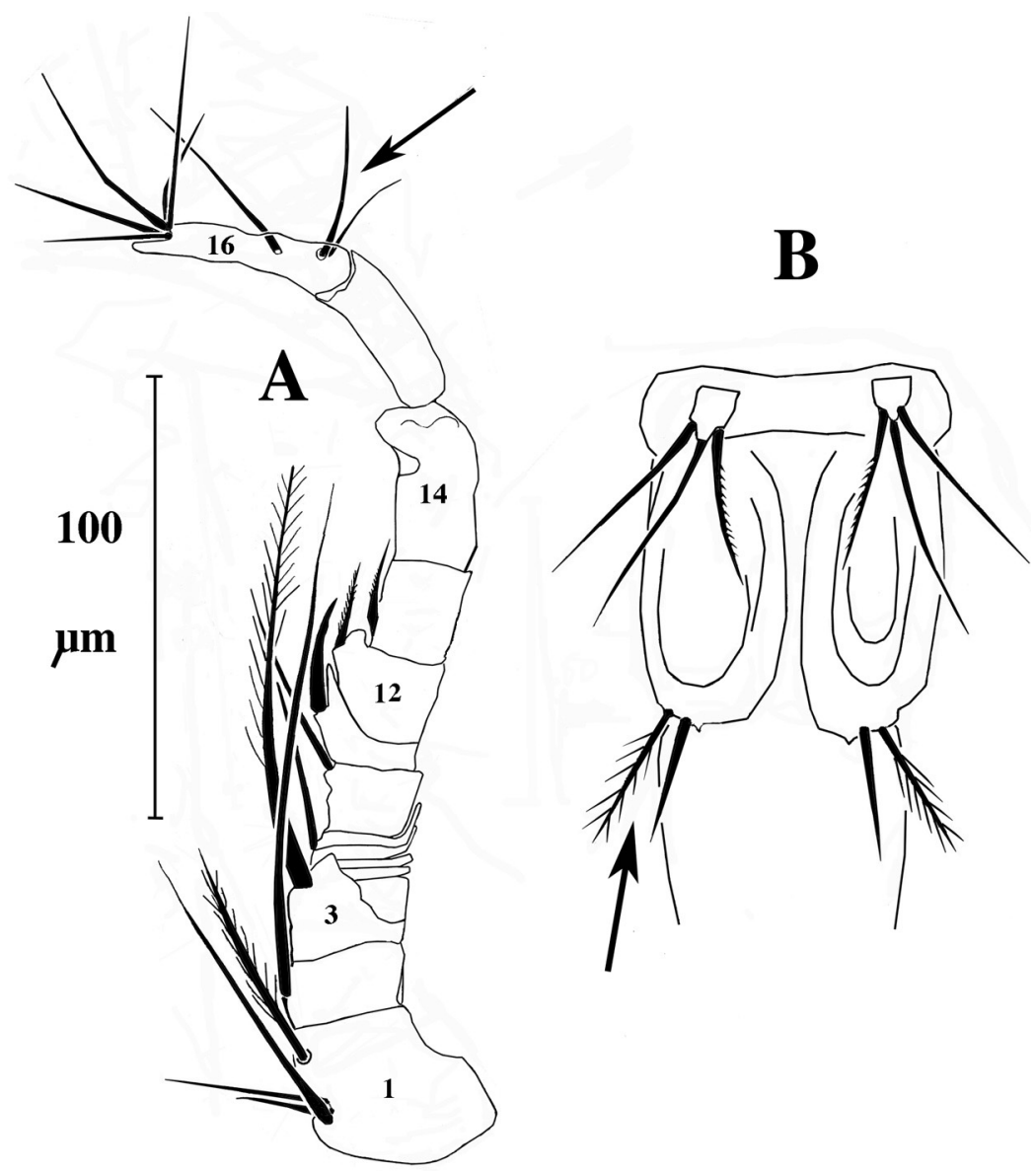

Fig. 9. Tropocyclops parvus Kiefer, male. A. A1, B. P5 and P6.

10; that on segment 9 reaches to the tip of segment 12 or slightly beyond it. A2 (Fig. 11) of the usual four segments; no spinules seen on the basipodite. Apical third of inner side of exopodite segment 2 with a short row of long, stiff setules (Fig. 12), gradually getting longer apicad. Apical third of exopodite 3 with a long setule followed by a short series of spinules. Mouth parts: mandible and maxillula as in T. jamaicensis Reid \& Janetzky (1996). Maxilla: second article with two almost equally sized setae; third article with a strong, denticulated claw and a slender seta; article 4 with two setae of similar size; article five with a slender seta and a couple of spines (Fig. 13B). Maxilliped (Fig. 13A) much as in $T$. jamaicensis. Apical segment with three setae, of which second-longest only about half as long as longest.

Swimming legs triarticulate (Fig. 14, Table 1), with spine formula $3: 4: 3: 3$. No spine rows seen on basi- and coxopodites. P1 with seta on the basis (Table 1) and a seta, shorter than the setae on segments 2 and 3, on the inner side of the basal segment of the exopodite. Exp1P2 with inner seta. Exp1P3 with outside spine stronger than subsequent three spines, slightly sinuous in shape, more deeply curved towards the segment that bears it than the subsequent spines (Fig. 14, arrow). A short seta at the inner apex of the same segment. Seta on inner apex of basal segment of endopodite, and basal seta of the pair on the second segment equally long and shorter than all more apically situated setae. P4: basal segment of exopodite with external shorter than the spines on the next segments; internally, a short seta. Internal apical seta on basal segment of endopodite relatively short, about half as long as the two setae on the second segment. Intercoxal sclerite not widening distally but strongly convex at its margin, with two short marginal rows of spinules, in contrast with the homologous sclerites of P1-P3, which are apically with two bulges but without marginal spinules. Long apical spine of enp3 P4 3-3.6 times as 


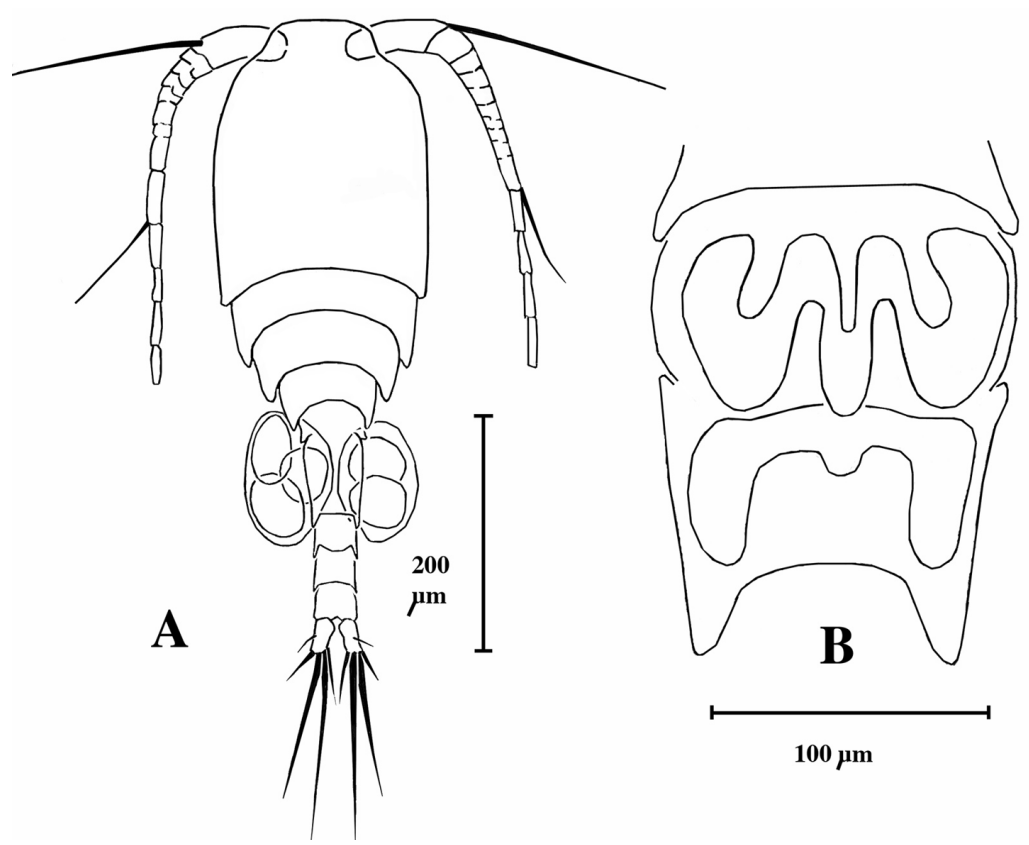

Fig. 10. Tropocyclops bopingi n. sp., female. A. Female habitus, B. Receptaculum seminis.

long as short apical spine (Table 2). P5 (Fig. 12B) small, a single segment, with relatively short, slightly sinuous spine and two plumose setae. Receptaculum seminis complex, with contorted arms, as in Figure 10B. Anal operculum simple, almost quadrangular (Fig. 12C). Furcal rami slightly over twice as long as wide, distinctly divergent; lateral setae inserted halfway their length. Internal median seta about 5 times as long as furcal rami and only about $20 \%$ longer than external median seta. Dorsal furcal seta long, about $70 \%$ of the length of the external median seta. Internal apical seta distinctly longer than external apical seta. All setae plumose, provided with long, spaced setules.

Description of the male-Smaller than the female, total size about $0.38-0.39 \mathrm{~mm}$. A 1 of 16 segments, geniculated between segments 14 and 15. Segment 11 dilated, obliquely traversed by a deep furrow (Fig. 15A) and with a movable hook. Long plumose setae on segments 1, 4, 6 extending beyond geniculation point. Two long setae springing from base of segment 16 much longer than the segment that bears them. Also, the longest seta of a tuft of setae at the tip of segment 16 much longer than that segment. Swimming legs as in the female, but P5 with a short internal spine, and P6 reduced to a single spine (Fig. 15B).

\section{Discussion}

\section{Morphological differences and relationships}

Although the description of new species in Tropocyclops is marred by the large number of incomplete and inaccurate descriptions that burden the literature, the current case is different, because its two closest relatives are here also redescribed. Kiefer (1931) used the spine formula as a fundamental character, defining a deep dichotomy within Tropocyclops. At the time of his paper, the spine formula 3:4:3:3 had been found only in T. confinis, beside in T. tenellus, and T. parvus. T. confinis is a much larger (at least $0.6 \mathrm{~mm}$ in body size) and robust animal that could hardly be confused with the tenellus-group. However, it shares a curious character with T. bopingi, viz. the spine on exp1P3, which in T. confinis is even more closely pressed against the segment than in bopingi, but whether or not this has phylogenetic meaning remains unclear. On the other hand, the tenellus-species group certainly will turn out to include more than three members. One obvious candidate is T. polkianus Einsle 1971, a pelagic animal from central Africa (Einsle 1971) that shares with $T$. bopingi and T. tenellus the long dorsal furcal seta, but has an even longer inner apical spine and an 


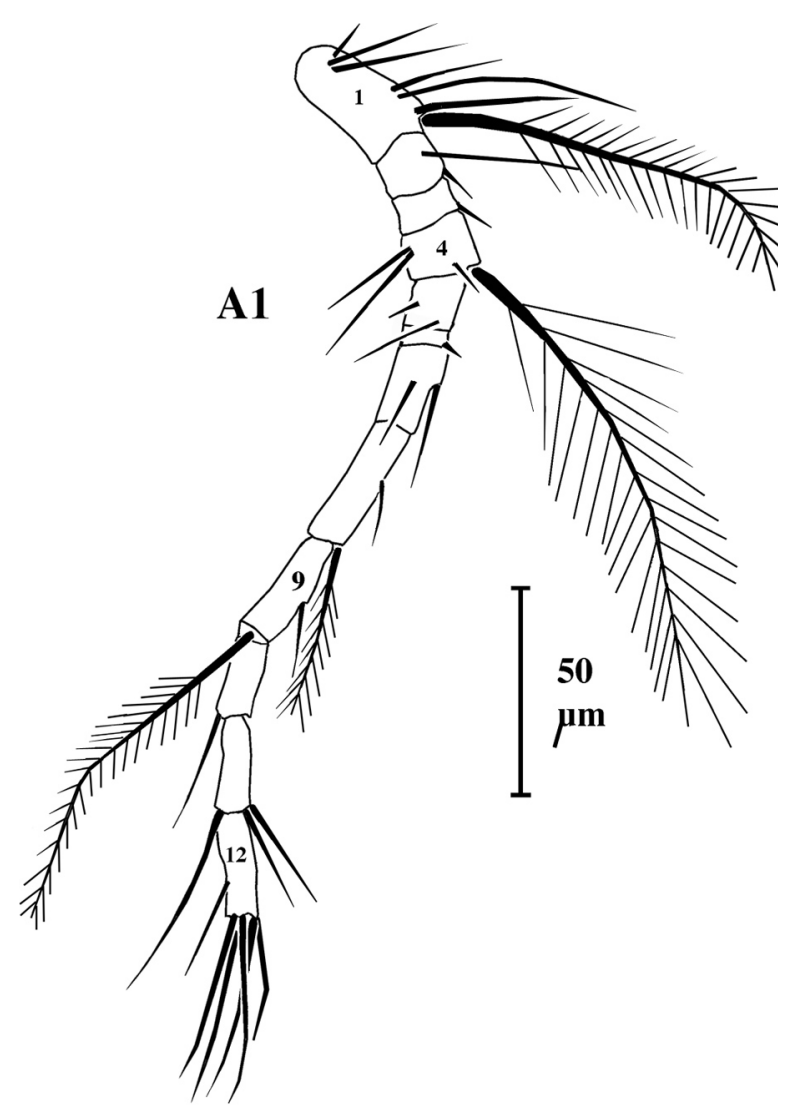

Fig. 11. Tropocyclops bopingi $\mathrm{n}$. sp., female. A1. even shorter outer apical spine on enp3P4 (Table 2). Its specific characters include its size (over $0.5 \mathrm{~mm}$ ), its apical internal furcal seta, shorter than the external furcal seta, and the lateral furcal seta implanted well distal of half the length of the rami. In the Fouta Djalon mountains, West Africa, Dumont (1981) found a Tropocyclops that might be related to polkianus but has a much shorter dorsal furcal seta, and the lateral furcal seta implanted about halfway the segment. The status of this animal remains unclear to date.

Of Tropocyclops tenellus Sars, several illustrations exist, beginning with the original description (Sars, 1909). They reveal that the taxon probably consists of a cluster of related species that share an extremely small size, making them the smallest pelagic cyclopoids known, and living under warm climatic conditions. Sars showed no seta on the basis of P1 and on enp1P1-P4, and this was confirmed by Kiefer (1956) and again in the present paper (Table 1). Einsle (1971) pictured animals from Lake Mweru in exactly the same way as Sars, but
Table 2. Length ratios on Enp3P4, taking short apical spine as unity.

\begin{tabular}{lccc}
\hline & $\begin{array}{c}\text { Short } \\
\text { apical } \\
\text { spine }\end{array}$ & $\begin{array}{c}\text { Long } \\
\text { apical } \\
\text { spine }\end{array}$ & Segment \\
\hline $\begin{array}{l}\text { T. tenellus } \\
\text { (Sars, Lake Tanganyika) }\end{array}$ & 1 & 5 & 2.3 \\
$\begin{array}{l}\text { T. tenellus } \\
\text { (Einsle, Lake Moero) }\end{array}$ & 1 & 5.1 & 3 \\
$\begin{array}{l}\text { T. tenellus } \\
\text { (Lake Tanganyika, this } \\
\text { paper) }\end{array}$ & 1 & 5.2 & 2.1 \\
$\begin{array}{l}\text { T. "tenellus" } \\
\text { (Dussart, Madagascar) }\end{array}$ & 1 & 3 & 1.5 \\
$\begin{array}{l}\text { T. bopingi } \\
\text { (this paper, Luixi He) }\end{array}$ & 1 & $3.0-3.6$ & 1.5 \\
$\begin{array}{l}\text { T. "parvus" (=bopingi) } \\
\text { Shen et al., Qianjang, } \\
\text { China) }\end{array}$ & 1 & 4 & 1.5 \\
$\begin{array}{l}\text { T. parvus } \\
\text { (Kiefer, Lake Petén, } \\
\text { Guatemala) } \\
\begin{array}{l}\text { T. parvus } \\
\text { (Lake Petén, this paper) }\end{array}\end{array}$ & 1 & 4 & 2 \\
$\begin{array}{l}\text { T. polkianus } \\
\text { (Einsle, Shiwa Ngandu, } \\
\text { Zambia) }\end{array}$ & 1 & 10 & 1.9 \\
\hline
\end{tabular}

added the intercoxal sclerite of P4. He depicted it as convex but without further details. The internal and external furcal setae are about equally long and the lateral furcal seta inserts halfway the rami. Harding (1942) verbally commented upon (but did not illustrate) animals from other lakes in the neighbourhood of Lake Tanganyika, and suggested that it might occur as far north as Ethiopia. Waya (2004) cited it from Lake Victoria. Dussart (1983), finally, reported T. tenellus from lakes in Madagascar. He showed an animal with the internal furcal seta slightly shorter than the external one. As in Sars' figures the dorsal furcal seta is just over half the length of the external median seta, and the lateral furcal seta inserts about halfway the ramus. Dussart is the only author who also pictures the male, showing a P6 with three appendages.

Tropocyclops tenellus can therefore be considered a morphologically well-characterized taxon, common in but not limited to Lake Tanganyika. The synonymy with T. parvus, proposed by Dussart \& Defaye (1985) is, however, debatable, because the latter taxon has never been 


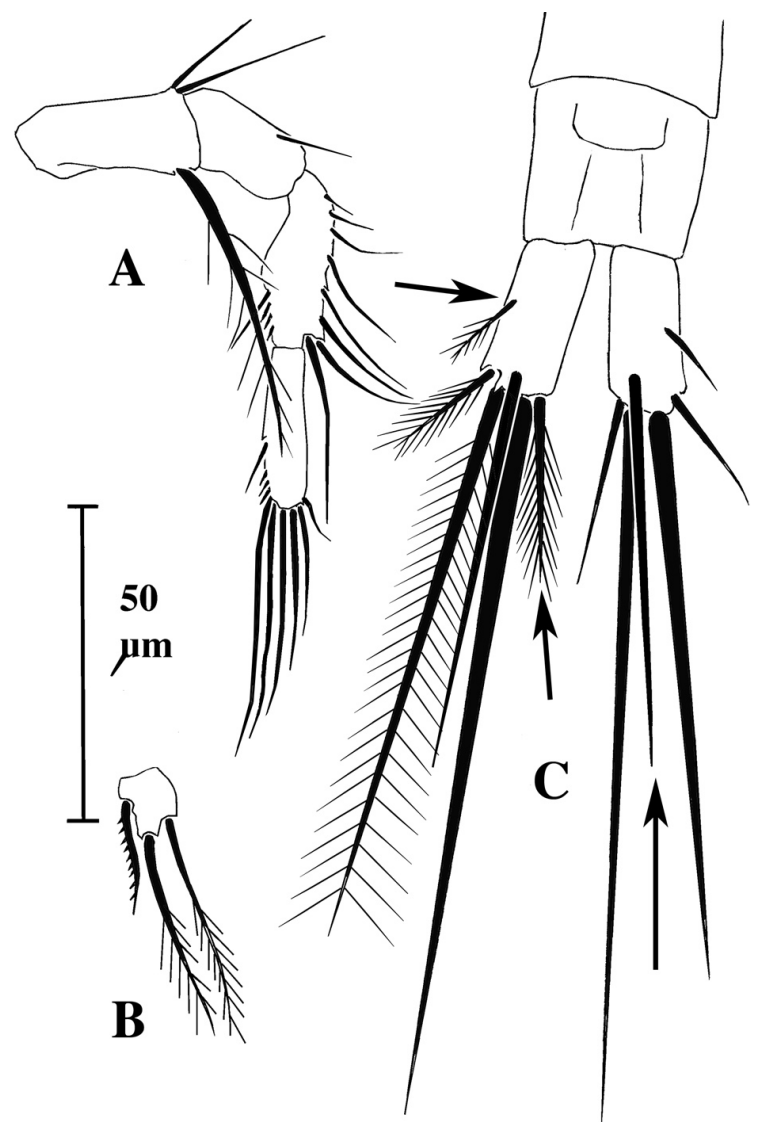

Fig. 12. Tropocyclops bopingi n. sp., female. A. A2, B. P5, C. Furcal rami.
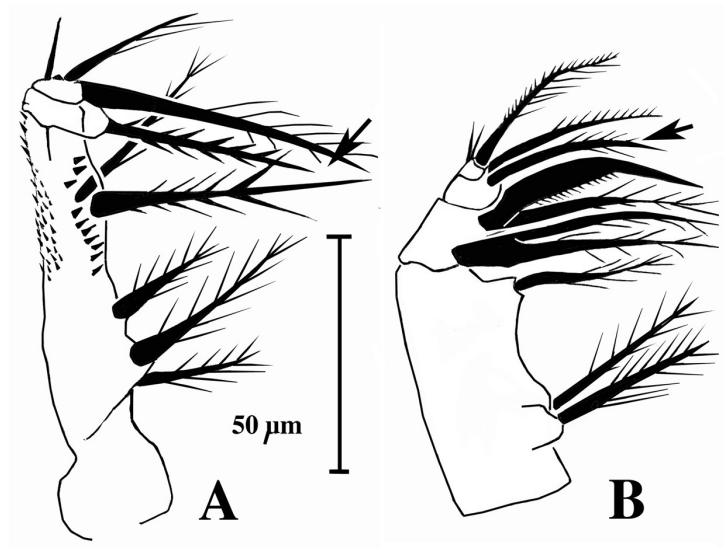

Fig. 13. Tropocyclops bopingi n. sp., female. A. Maxilliped, B. Maxillula adequately described. Our illustrations and Tables 1 and 2 show that it has unique characters on enp1 and enp2P1, and in the armament of the furca (especially the relatively short dorsal seta), while the long setae of its A1 are distinctly shorter than in tenellus and bopingi in both sexes, and its male $\mathrm{P} 6$ is the only one that has two spines. On the other hand, it shares with bopingi the presence of a seta on the basis of P1, and internal setae on exp1P3-4 (these setae are lacking in tenellus). In addition, the spine formula of T. parvus is variable, even within single individuals. The case is reminiscent of that of Acanthocyclops robustus-vernalis (Kiefer, 1976), where the spine formula varies in the same way. It is unclear what significance should be attached to this phenomenon.

Shen et al. (1979), in their fauna of China, used the name parvus for a small Tropocyclops found in Qianjiang, middle Yangtze valley, following a nomenclatorial suggestion by Lindberg (1955). However, the set of characters situated on enp3P4 (see Table 2) such as the length relationship of the long apical spine, short apical spine (here take as unity), and the enp3P4 show that they did not

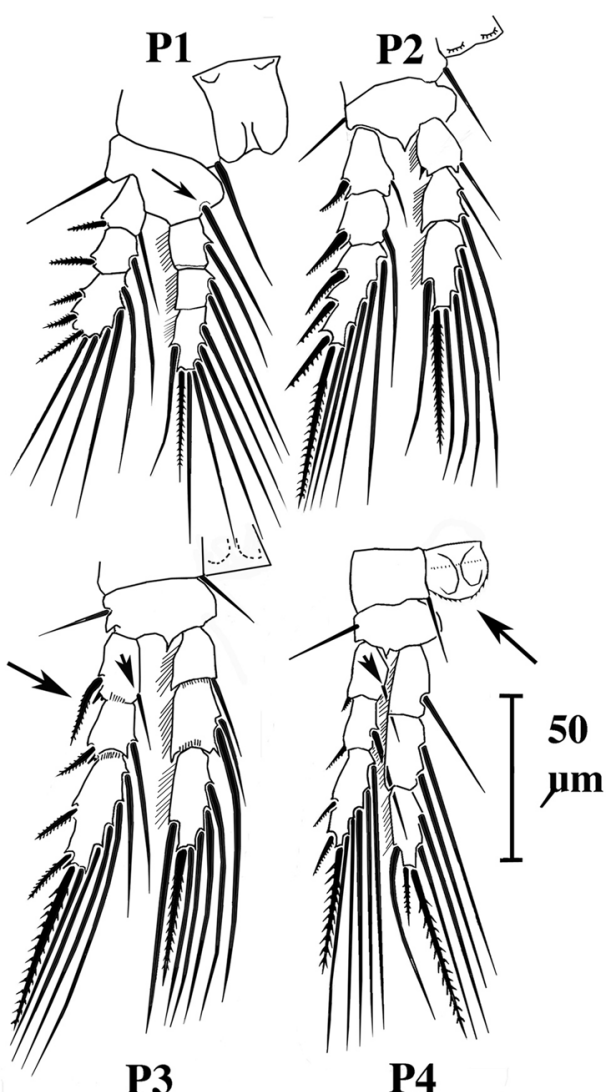

Fig. 14. Tropocyclops bopingi n. sp., female, P1-P4. 
have T. parvus, but T. bopingi before them. Further support for this is in the length relationships of the furca: the internal medial seta is 5 times the length of the rami in $T$. parvus and in T. bopingi, while it is over 6.5 in African tenellus (including the Madagassian taxon). Table 2 also suggests that the Madagassian taxon merits further study: it does belong to the tenellus group sensu stricto, but it may be endemic to the island. Perhaps populations from other parts of Africa should also be re-studied, especially in view of the particular habit of the Lake Tanganyika population of not carrying its eggs attached. Dussart \& Fernando (1985), finally, described a T. pseudoparvus from Costa Rica. It is a small $(0.5 \mathrm{~mm})$ species that superficially resembles the tenellus-group, yet has a spine formula 2.3.3.3, which immediately sets it apart from all others.

I conclude that the three species discussed here are closely related and part of a natural group, with T. tenellus and bopingi the species best adapted to a pelagic mode of life and more closely allied to each other than to T. parvus.

\section{Ecological considerations: is small beautiful in the pelagic?}

Can it be a coincidence that as well in Africa, South East Asia, and Central America extremely minute (0.3-
$0.4 \mathrm{~mm}$ ) species of Tropocyclops occur in the limnetic zone of lakes and reservoirs and, if not, what could be the ecological background of this phenomenon? The pelagic nature of the tenellus-group animals is above suspicion: in lake Victoria, they take part in diurnal vertical migration (Waya 2004), and in Lake Tanganyika, they seem restricted to the top $40 \mathrm{~m}$ of this extremely deep lake. True T. tenellus, with its long plumose antennae providing buoyancy, is doubtlessly the best adapted to living in the pelagic, and T. parvus the least.

To better understand their position in the food web, it is useful to have a brief look at the species they coexist with, competitors as well as predators. As to their own food regime: all Tropocyclops species so far studied are omnivores. Adrian \& Frost $(1992,1993)$ collected experimental evidence to show that in cyclopoids, the smaller the body size, the more important the non-animal part of the diet. Diéguez \& Gilbert (2002) found that in T. extensus, a $0.6-0.7 \mathrm{~mm}$ species widespread in North America, algae but also small rotifers were well represented in the daily ration. There is no hard information on the diet of the tenellus-group, but it seems obvious that micro-algae and the occasional protozoan should form the bulk of their ration, putting them in competition with cladocerans and with the immature stages of other cyclopoids like Thermocyclops spp. and Mesocyclops spp.

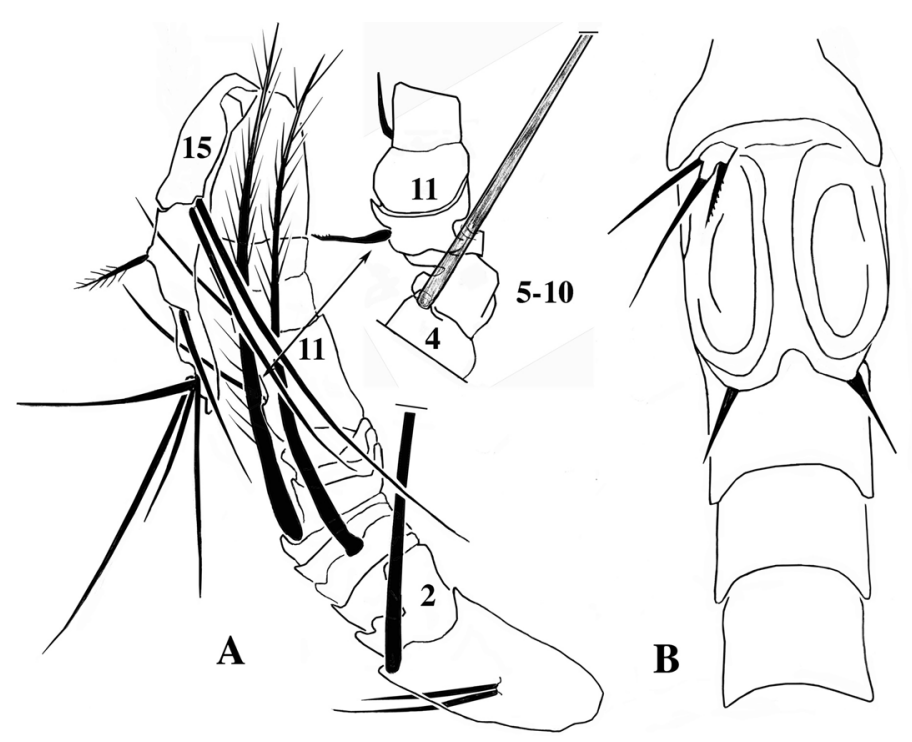

Fig. 15. Tropocyclops bopingi n. sp., male. A. A1, B. P5-P6. 
Tropocyclops species are preyed upon by invertebrate predators and small fish. Upon its introduction to Harp Lake, Canada, for example, Bythotrephes longimanus caused a significant reduction of the stock of the relatively large T. extensus (Dumitru et al. 2001). Liuxi He reservoir has been artificially cleared of fish a number of years ago, but the following pelagic invertebrate predators live there in sizeable numbers: Leptodora kindtii, Chaoborus, rhabdocoelid flatworms, and Mesocyclops thermocyclopoides. However, this South Chinese lake is situated in a transition zone towards the tropics: Daphnia, typically absent from tropical lowlands waters, is still well represented, as well as Leptodora, but both are close to their limit of south-eastern extent here. For prey, adult Leptodora and similar predators have a choice between Daphnia (of the longispina group), Moina micrura, Ceriodaphnia cornuta, Bosmina longirostris, Diaphanosoma orghidani, Phyllodiaptomus tunguidus, and three species of cyclopoids, strongly different in size, and with Tropocyclops by far the smallest. Possibly, its small size provides it with a selective advantage in such a warm, high-predation environment, because below a given threshold of size, predators might lose interest or be incapable of handling such prey. On the other hand, Tropocyclops may suffer competition and perhaps even predation from other cyclopoids. In Liuxi He, the largest cyclopoid is Mesocyclops thermocyclopoides. It is almost certainly carnivorous. Thermocyclops taihokuensis stands halfway in size between Mesocyclops and Tropocyclops. In Adrian \& Frost's $(1992,1993)$ logic, it should be partly herbivorous, partly carnivorous. It may as well compete with Tropocyclops for food as feed on it.

In Lake Tanganyika, where cladocerans are absent (Coulter 1991, Dumont 1994) the competitors facing T. tenellus would be the younger copepodid stages of the cyclopoids Thermocyclops and Mesocyclops equatorialis, and the filter-feeding calanoid Tropodiaptomus simplex, while its predators include the small sardines Limnothrissa and Stolothrissa, adult cyclopoids, the medusa Limnocnida tanganyikae, and perhaps a flock of endemic pelagic shrimp of the genus Limnocaridina. To date, no studies document the feeding ecology of these small shrimp, but at least its larger relative Caridina nilotica in Lake Victoria has been shown to be a facultative carnivore, especially at night (Lehman et al. 1996). The diet of Stolothrissa has been best studied by Chéné (1975), who found that it exploits zooplankton patches on a "first meet, first eat" basis, and thus its stomach contents vary with the type of zooplankton patches it encounters. It feeds visually, mainly at dawn and dusk, while the predatory cyclopoids probably mostly feed during their nocturnal upward migration. Chéné only occasionally found T. tenellus in the stomach contents of Stolothrissa, yet the associated selective pressure may have been sufficient for it to become as small and invisible as possible (inter alia, by suppressing its egg-carrying habit). As to the Limnocaridina, these small, vertically migrating shrimp have excellent eyes, and they might feed visually before their morning descent to deeper waters. Whether they use this window of opportunity to catch Tropocyclops, or whether they only attack larger prey is, however, unknown. The jellyfish Limnocnida could also attack Tropocyclops. Being eyeless, it feeds in a tactile (nonvisual) way, and might strike at its prey at any moment of the diurnal cycle. However, most medusae sink to deep layers during daytime, and thus predation risk for the Tropocyclops is mostly during the night. The two large cyclopoids of Lake Tanganyika are certainly capable of feeding on Tropocyclops; yet, like all other invertebrates and even Stolothrissa, they too reside in deeper water layers during daytime. The continuous residence of Tropocyclops in the epilimnion can thus be interpreted as a mechanism to reduce its time of exposure to potential predators, and its small size and habit of producing eggs one by one an adaptation for remaining invisible in the clear surface waters of the lake.

In Lake Petén Itzá, at least three pelagic fish species, with the clupeid Dorosoma petenense most prominent, feed on zooplankton. The grazing zooplankton is simple and consists of a few small-sized cladoceran species (Eubosmina tubicen, Bosminopsis deitersi, Ceriodaphnia sp.) and is dominated by a small and extremely transparent calanoid, Arctodiaptomus dorsalis (Deevey et al., 1980). Judging by its small size and the large numbers present, this might be the main local competitor of Tropocyclops parvus. At the time of sampling (March 2006), T. parvus was not rare, but it was not an abundant element of the pelagic zooplankton either. Invertebrate predators included few Mesocyclops edax and Thermocyclops inversus. Curiously, the endemic pelagic ostracod Cypria petenensis was not seen. The only large invertebrate carnivore present is the larva of Chaoborus. Deevey et al. (1980) found that its diurnal migratory amplitude in a side basin of the Petén valley was about $20 \mathrm{~m}$, while the crustacean zooplankton moved up only about 5-10 m during the night. Unfortunately, all cyclopoids were lumped such that it is not possible to decide whether $T$. parvus vertically segregated from the other two species, although all cyclopoids together distinctly avoided the Chaoborus zone.

In summary, in the lake environments examined here, the pelagic Tropocyclops need to compromise between a suite of competitors and a mix of visual and non-visual predators, a trade-off resulting in a selection for small 
size. This may specialize them for a type of food unattractive to larger cyclopoids (adult and late copepodid stages). The element of predator avoidance appears to have become maximally expressed in $T$. tenellus of lake Tanganyika: this species reduces contact with other zooplankters by its epilimnetic mode of life, no doubt facilitated by its superior buoyancy. In addition, its smallness and transparency render it hard to detect to visual predators, a strategy perfected by the fact that it avoids carrying its eggs, since egg balls might render it more visible. In conclusion, it appears that in warm lakes at the margin of the tropics (either by latitude, as in South East Asia and Central America, or by altitude as in CentralAfrica), a selective pressure exists that favours at least one small omnivorous Tropocyclops in the pelagic.

\section{Acknowledgements}

I thank Prof. Dr Boping Han (Jinan University, Guangdong, China) and his students for taking me out to Liuxi He reservoir during the international zooplankton course in Guangzhou, China, June 2005, and again in 2006. Dr Manuel Elias Gutiérrez (Chetumal, Mexico) organized a special expedition to Guatemala, and guided me to and on Lake Petén. In addition, I benefited greatly from his deep insights into the ecology of the lake. To Prof. Dr Jean-Pierre Descy (Namur, Belgium) I extend my warmest thanks for making available his rich collection of samples from Lake Tanganyika to me, including some vertical zooplankton series.

\section{References}

Adrian R. \& Frost T.M. 1992. - Comparative feeding ecology of Tropocyclops prasinus mexicanus (Copepoda, Cyclopoida). J. Plankton Res., 14, 1369-1382.

Adrian R. \& Frost T.M. 1993. - Omnivory in cyclopoid copepods comparison of Algae and invertebrates as food for three, differently sized species. J. Plankton Res., 15, 643-658.

Chéné G. 1975. - Etude des problèmes relatifs aux fluctuations piscicoles du Lac Tanganika. Thesis, Liège University, 108 pp.

Coulter G. W. (ed.) 1991. - Lake Tanganyika and its Life. Natural History Museum \& Oxford University Press, London, 354 pp.

Deevey E. S., Deevey G.B. \& Brenner M. 1980. - Structure of Zooplankton Communities in the Peten Lake District, Guatemala. In W. C. Kerfoot (Ed.), Evolution and Ecology of Zooplankton Communities. University Press of New England, Hanover, New Hampshire, pp. 669-678.

Diéguez H. C. \& Gilbert J.J. 2002.- Suppression of the rotifer Polyarthra remata by the omnivorous copepod Tropocyclops extensus: predation or competition? J. Plankton Res., 24, 359369.

Dumitru C, Sprules W.G. \& Nyam N.D. 2001. - Impact of Bythotrephes longimanus on zooplankton assemblages of Harp Lake, Canada: an assessment based on predator consumption and prey production. Freshwat. Biol., 46, 241-251.
Dumont H. J. 1981. - Cladocera and free-living Copepoda from the Fouta Djalon and adjacent mountain areas in West Africa. Hydrobiologia, 85, 97-116.

Dumont H. J. 1994. - Ancient lakes have simplified pelagic food webs. Arch. Hydrobiol. Beihefte, 44, 223-234.

Dussart B. 1969. - Les Copépodes des eaux continentales d'Europe Occidentale. Tome II. Cyclopoides et Biologie. Boubée, Paris, 292 pp.

Dussart B. 1982. - Crustacés Copepodes des eaux intérieures. Faune de Madagascar 58, 146 pp. ORSTOM - CNRS, Paris.

Dussart B. \& Defaye D. 1985. - Répertoire mondial des Copepodes Cyclopoides. CNRS, Paris, 236 pp.

Dussart B. H. \& Fernando C.H. 1985. - Remarks on two species of copepods in Costa Rica, including a description of a new species of Tropocyclops. Crustaceana, 50, 39-44.

Einsle U. 1971. - Freeliving Copepods. In J. J. Symoens (ed.), Hydrobiological survey of the Lake Bangweulu and Luapala River basin, 13 (1): 74 pp. Cercle Hydrobiologique de Bruxelles, Brussels.

Harding J. P. 1942. - Cladocera and Copepoda collected from East African Lakes by Miss C. K. Ricardo and Miss R. J. Owen. Ann. Mag. Nat. Hist., 11, 9, 174-191.

Holynska M., Mirabdullayev, I.M., Reid J.W. \& Ueda H. 2003. Copepoda Cyclopoida. Genera Mesocyclops and Thermocyclops. In H.J.Dumont (ed.), Guides to the identification of the Microinvertebrates of the continental waters of the world 20: 318 pp. Backhuys, Leiden.

Huys R. \& Boxshall G.A. 1991. - Copepod Evolution. The Ray Society, London, 468 pp.

Kiefer F. 1931. - Die Untergattung Tropocyclops der Gattung Eucyclops (Copepoda: Cyclopoida). Zeitschr. Wissensch. Zool., 138, 487-514.

Kiefer F. 1956. - Ruderfusskrebse aus dem Tanganjikasee. Rev. Zool. Bot. afr., 44, 241-266.

Kiefer F. 1976. - Revision der robustus-vernalis-Gruppe der Gattung Acanthocyclops Kiefer (Crustacea, Copepoda). Beitr. Naturk. Forsch. Sudwestdeutsch., 35, 95-110.

Lehman J. T., Mbahinzireki G.B. \& Mwebaza-Ndawula L. 1996. Caridina nilotica in Lake Victoria: abundance, biomass, and vertical migration. Hydrobiologia, 317, 177-192.

Lin Q-Q, Duan, S.S., Hu R. \& Han B. 2003. - Zooplankton distribution in tropical reservoirs, South China. Int. Rev. Hydrobiol., 88, 602-613.

Lindberg K. 1955.- Cyclopides (Crustacés Copépodes) récoltés au Pérou par le Dr Hernando de Macedo. Folia biol. andina, II. Zoology, 1, 1-18.

Reid J.W. \& Janetzky W. 1996. - Colonisation of Jamaican bromeliads by Tropocyclops jamaicensis $\mathrm{n}$. sp. (Crustacea: Copepoda: Cyclopoida). Invertebrate Biology, 115, 305-320.

Sars G.O. 1909. - Zoological results of the third Tanganyika expedition conducted by Dr W.A. Cunnington, F.Z.S., 19041905. Report on the Copepoda. Proc. Zool. Soc. Lond., 1909, 3177,17 plates.

Shen S-J., Tai A.Y., Chen G.X. and others, 1979. - Fauna Sinica. Crustacea, Freshwater Copepoda. Sceince Press, Peking, 450 pp (in Chinese).

Waya R.K. 2004. - Diel vertical migration of zooplankton in the Tanzanian waters of Lake Victoria. Tanzania J. Sci., 30, 123-134. 
